Kansas State University Libraries

New Prairie Press

Academic Chairpersons Conference

35th Academic Chairpersons Conference,

Proceedings

Orlando, FL

\title{
Reflective Leadership Practice for Academic Chairs
}

Sue Wells

Centennial College of Applied Arts and Technology, swells@centennialcollege.ca

Marilyn Herie

Centennial College of Applied Arts and Technology, mherie@centennialcollege.ca

Follow this and additional works at: https://newprairiepress.org/accp

Part of the Educational Leadership Commons, and the Higher Education Administration Commons

(c) (i) (2)

This work is licensed under a Creative Commons Attribution-Share Alike 4.0 License.

Recommended Citation

Wells, Sue and Herie, Marilyn (2018). "Reflective Leadership Practice for Academic Chairs," Academic Chairpersons Conference Proceedings. https://newprairiepress.org/accp/2018/leadership/2

This Event is brought to you for free and open access by the Conferences at New Prairie Press. It has been accepted for inclusion in Academic Chairpersons Conference Proceedings by an authorized administrator of New Prairie Press. For more information, please contact cads@k-state.edu. 


\section{Reflective Leadership Practice for Academic Chairs}

Ready, set....pause. This session provides participants with the time and space to step away from the daily stresses of being a chair person and begin to focus on their personal roadmap for leadership growth. Introducing the book Academic Leadership: A Reflective Practice Guide for Community College Chairs this highly interactive session guides the participants through a series of reflective exercises and discussions that will help them clarify how their leadership values can and should shape their practice and how they can begin to use this knowledge to develop their full potential as a chair.

Participants will then be exposed to a variety of tools that they can use to collect data about their effectiveness as a chair and their leadership style. Risky - yes! Rewarding - absolutely! As a department Chair there are a number of quantitative (as well as some qualitative) indicators that (in part) evaluate performance. These include academic programs score on college-wide Key Performance Indicators, a department's "engagement score" on institution-wide employee engagement surveys, student enrolment in academic programs, and the extent to which the department meets projected budget targets. While the chair's management style and effectiveness undoubtedly impact these metrics, there are many other internal and external factors that carry significant weight and influence. The data collection tools provided in this session have a different focus than data from Key Performance Indicators, employee engagement scores, enrollment targets or budgets. The tools introduced in this workshop will help chairs to collect information that is directly reflective of them.

In the final segment of this session, participants will apply their earlier reflections to the task of creating a high functioning and positive department. We all want to lead departments where people enjoy the job they do and feel valued and respected in the workplace. Differing personalities and the dynamics amongst group members can create havoc within a department. Through personal leadership stories and case studies, proactive and reactive strategies and practices used to create a high functioning and positive department culture will be shared and opportunity provided to network with colleagues to share ideas and learn from others successes.

At the conclusion of this workshop, chairs will be able to:

1. Identify the values that inform their leadership practice and analyze their leadership practice for congruency with their guiding values.

2. Collect meaningful feedback to inform personal reflection regarding their leadership.

3. Begin to formulate or enhance a leadership strategy for improving the culture of their department. 
Handouts will be adapted from the book Academic Leadership: A Reflective Practice Guide (https://www.amazon.ca/s/ref=nb sb noss/145-4423119-0448516?url=searchalias\%3Daps\&field-keywords=Academic+leadership+reflective) for Community College Chairs and provided for participants to use and take back to their colleges. 